6. Stawicki SP, Evans DC, Cipolla J, Seamon MJ, Lukaszczyk JJ, Prosciak MP, et al. Retained surgical foreign bodies: a comprehensive review of risks and preventive strategies. Scand J Surg. 2009. Vol. 98. N. 1. P. 817.

7. Stawicki SP, Moffatt-Bruce SD, Ahmed HM, Anderson HL, 3rd, Balija TM, Bernescu I, et al. Retained surgical items: a problem yet to be solved. J Am Coll Surg. 2013. Vol. 216. N. 1. P. 15-22.

8. Wan W, Le T, Riskin L, Macario A. Improving safety in the operating room: a systematic literature review of retained surgical sponges. Curr Opin Anaesthesiol. 2009. Vol. 22. N. 2. P. 207-14.

9. Wieder HA FH, Rummeny EJ, Gaa J. Radiological diagnosticsfor iatrogenic retained foreign bodies after surgery. Chirurg. 2007. Vol. 78. P. 22-27.

10. Zbar A.P., Saeed I.T., Utidjian M.R. Gossypiboma revisited: a case report and review of the literature. J R Coll Surg Edinb. 1998. Vol. 43. P. 417-418.

11. Zejnullahu V.A., Bicaj B.X., Zejnullahu V.A., Hamza A.R. Retained Surgical Foreign Bodies after Surgery. Open Access Maced J Med Sci. 2017. Vol. 5, N. 1. P. 97-100.

DOI https://doi.org/10.30525/978-9934-588-81-5-1.50

\title{
ПСИХОЛОГІЧНА ДІАГНОСТИКА БОЛЬОВОГО СИНДРОМУ
}

\author{
Фітькало О. С. \\ кандидат медичних наук, \\ доиент кафедри психіатрії та психотерапії \\ факультету післядипломної освіти \\ Львівського національного університету імені Данила Галицького \\ м. Львів, Украӥна
}

Швидкий розвиток сучасного урбанізованого суспільства призводить до збільшення його впливу на особистість, що характеризується як «тиск» на психіку, яка шляхом усунення надмірного емоційного напруження запобігає дезорганізації поведінки через прояви болю. Така біль трактується як болісний спосіб примирення індивіда 3 неприйнятною для нього інформацією і являється його психічним захистом. Питання боротьби людини з болем своїми коренями веде в глибину століть. Про це свідчать усні перекази старовини, древні міфи висічені на камені та записані на старовинному пергаменті, художні 
твори всіх часів і народів. Вчення про біль має таку ж тривалу історію розвитку, як і саме людство[1]. Зв'язок між болем та больовою поведінкою $є$ предметом дискусій вчених різних наукових напрямків, таких як фізіологія, психологія, медицина і навіть філософія.

Створений самою природою в результаті еволюційного розвитку живих істот біль тривалий час у народі сприймався як «справедлива кара божа», як «шосте чуття», схоже на зір, смак, слух, відчуття дотику й нюху. Однак на відміну перерахованим відчуттям біль виникає при інтенсивному подразненні різних сенсорних рецепторів (температури, тиску та ін.). Разом з тим у виникненні й підтримці болю задіяні такі компоненти, як свідомість, пам'ять, вегетативні, соматичні, поведінкові реакції, емоції. У свій час Церква проповідувала, що біль очищає тіло і рятує душу і тому не потрібно боротися 3 нею. Незважаючи на такі застереження, людина завжди прагнула любим чином позбутись болю. А больова поведінка була тим своєрідним індивідуальним больовим «термометром», який демонстрував ознаки болю, виступаючи інструментом комунікації i, відповідно, впливав на оточення [2].

3 кожним роком зростає інтерес до проблеми болю, враховуючи, що немає сьогодні людини, яка б не відчувала страждань у вигляді різних видів болю протягом життя. Важливо зазначити, що багато фізіологічних функцій, в тому числі і відчуття болю, певною мірою визначаються індивідуальними особливостями. Зрозуміло, що біль нерозривно пов'язаний з емоційними переживаннями, які впливають на спосіб життя людини, стають головним мотиваційним чинником, що визначає всю його подальшу поведінку і вчинки [3]. Біль безпосередньо впливає на свідомість, емоції, пам'ять, соматичні, вегетативні і поведінкові реакцій. Тільки за участі свідомості і психіки людина може оцінити больові відчуття, які виникають. Нарешті, біль, особливо хронічна, може стати прогностичним чинником соматичних хвороб, біль пригнічує імунітет, прискорює ріст пухлин.

На сьогодні одним із важливих діагностичних критеріїв у постановці діагнозу, ефективності лікування й настання видужання пацієнта залишається біль. Феномен болю не обмежується винятково органічними чи функціональними порушеннями в місці його локалізації, а проявляється вегето-соматичними реакціями та характеризується певними психоемоційними складовими. Будь-яке хронічне захворювання або нездужання, що супроводжується болем, впливає на емоції й поводження особистості, часто веде до появи тривоги й напруги, що в свою чергу посилює сприйняття болю. Психологічні наслідки болю 
можуть проявлятися у вигляді гніву, дратівливості, почуття страху й тривоги, обурення, занепаду духу, зневіри, депресії, втрати інтересу до життя, зниження сексуальної активності, які в свою чергу впливають на яскравість, емоційне забарвлення больового синдрому і в кінцевому варіанті ведуть до появи тривожно-депресивного розладу [6]. Тому особливістю діагностики будь-якого болю є не об'єктивні ознаки, які лікар виявляє при огляді, а, в першу чергу, скарги пацієнта. Твердження, що біль може бути винятково психогенного походження, $\epsilon$ дискусійним. Однак широко відомо, що особистість формує больове відчуття, яке завищене в істеричних особистостей, і більш точно відбиває реальність у пацієнтів не істероїдного типу. Тому індивідуальні типологічні особливості, біопсихосоціальний статус пацієнта можна розглядати як важливі конституційні складові клініко-патогенетичних механізмів хронічних болей.

Для проведення диференційної діагностики 3 метою оцінки стану емоційно-особистої сфери 33-м пацієнтам віком 27-65 років, які звернулись зі скаргами на болі в спині, пропоновано психологічне обстеження. Обстеження проводилось 3 використанням таких психологічних тестів: шкали самооцінки (Спілбергера -Ханіна), шкали депресії Гамільтона, шкали самооцінки тривоги (Чабан О.С., Хаустова Е.А.), опитувальника Айзенка. Вираженість болю оцінювали за допомогою візуальної аналогової шкали (ВАШ). Для об'єктивної оцінки больової реакції у хворих на тлі фармакологічної корекції при застосуванні антибольової й седативної медикаментозної терапії було використано динамічну реєстрацію діаметра зіниці ока (пупілоалгометрію) [5]. Всім пацієнтам для підтвердження діагнозу було проведено комплексне неврологічне обстеження.

За результатами дослідження діагностовано депресивний синдром у $58 \%$ пацієнтів, майже у 73 \% пацієнтів виявлено тривожнодепресивний розлад. Характерними симтомами у даної групи пацієнтів були: порушення сну, зниження настрою, тривога, напруженість, безпричинний страх, вегетативні розлади. Больовий синдром за 10-бальною ВАШ був оцінений у $6,9 \pm 0,3$ бала в пацієнтів із депресивними проявами і в 5,5 \pm 0,2 бала в пацієнтів без них. Особливо яскраво вираженими психоемоційні порушення спостерігались у пацієнтів холеричного й меланхолічного типів (за опитувальником Айзенка). У пацієнтів меланхолічного темпераменту больовий синдром виявлено у 69 \% випадків на фоні депресивних проявів, у сангвініків - без них. Яскравість больового синдрому мала такі тенденції: була вищою в осіб меланхолі- 
чного і холеричного типів $(6,7 \pm 0,2$ та $6,3 \pm 0,2$ особи), нижче - у сангвінічного і флегматичного типів (5,9 $\pm 0,2$ та 4,8 $\pm 0,3$ особи).

Пацієнтам проводили також вимір площі й тривалості розширення зіниці за даними пупілограми, що зменшило суб'єктивність в оцінці больових реакцій пацієнта та дозволило підвищити об'єктивність визначення ефективності впливу анальгетиків, седативних препаратів й транквілізаторів на ноцицептивну систему хворих. Лікування було ефективним, коли тривалість та площа розширення зіниці ока під час повторного вимірювання була меншою від попередньої на 25 відсотків й більше.

Висновок. Вважаємо, що психодіагностика болю $є$ важливим показником при дослідженні пацієнтів із больовими синдромами. Тому рекомендовано фізіологічні показники використовувати у поєднанні 3 психологічними шкалами, оскільки існує чимало причин, що можуть спотворити їх інтерпретацію. Психологічне тестування доповнює клінічне обстеження пацієнта об'єктивними критеріями, що збільшує достовірність діагностики больового синдрому на ранніх стадіях його прояву.

\section{Література:}

1. Голубева В.Л. Болевые синдромы в неврологической практике. 3-е изд. перераб. и доп. М.: МЕДпресс-информ, 2010: 336 с.

2. Галян АІ. Психофізіологія болю та особливості його контролю у дітей і підлітків. Теорія і практика сучасної психології. 2019; 1 (1): 119-23.

3. Мачерет Є. Л., Чуприна Г. М., Морозова О. Г.. Патогенез, методи дослідження та лікування больових синдромів: посібник. Х. : ВПЦ Контраст, 2006. 168 с.

4. Мурашко Н.К. Нейропатическая боль: тактика лечения. Врачебное дело. 2012; 6: 106-113.

5. Фітькало О.С., Мокрик О.Я. Патент № 94792 U Спосіб експресоцінки вегетативної реакції людини на больовий чинник за допомогою цифрової реєстрації діаметра зіниці ока.

6. Stevens B., Harrison D., Rashotte J. et al. Pain assessment and 3. intensity in hospitalized children in Canada. J Pain. 2012; 13: 857-65. 